\title{
Die groot maroelas
}

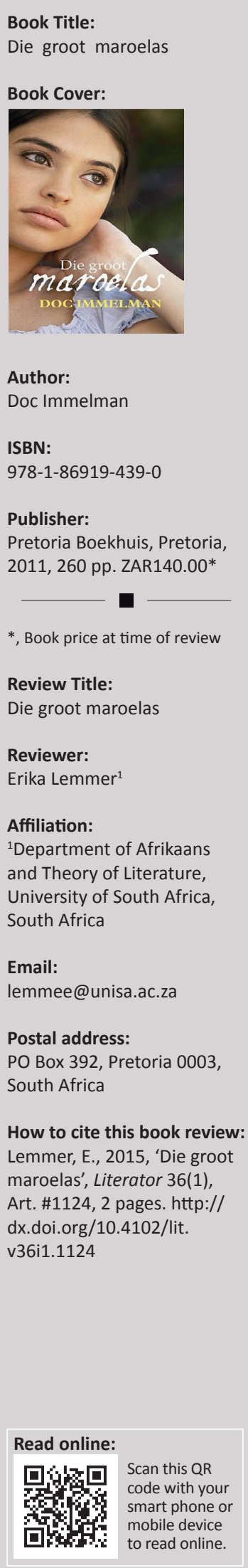

Daniel Ferdinand (Doc) Immelman (1928-2013) se tekste verwoord deurgaans die genius loci, die gevoelstemming, die onsigbare gees van die ou Suidwes-Afrika (vandag Namibië). Met Die groot maroelas (heruitgegee deur Protea Boekhuis in 2011) is dit dan ook nie anders gesteld nie. Op die kleurryke Immelman se amptelike webtuiste (http:/ / www.docimmelman.com) verwoord sy dogters hulle pa se intieme vereenselwiging met dié land soos volg:

' $n$ Suidwester in been en bloed, hart en siel. Ons pa is aanmekaargeweef van kameeldoringhout en rooi duinesand, van salpeter op 'n perd se nek, van die vaal Suidwes-winterveld, die blou-blou lug, van koedoebiltong en potgebraaide springbokboud, van kampvuur onder die suider-sterrehemel en van duisende woorde en sinne en stories.

Doc Immelman word saam met Christiaan Bakkes en Piet van Rooyen wyd beskou as die Afrikaanse 'Suidwes-skrywers' (Smith 2002:6). Immelman word meermale die 'Hemingway van Namibië' genoem (La Vita 1994:18). Hy erken in 'n onderhoud met Smith (2002:6) ook dat hy terdeë beïnvloed is deur skrywers soos De Maupassant, Hemingway en Steinbeck en beskryf sy liefde vir Namibië as iets wat grens aan hartstog en jaloesie. Van Rooyen (2002) meen selfs dat hierdie tekste grootliks bygedra het tot die vorming van leserspersepsies oor die omgewing en geskiedenis van die ou Suidwes-Afrika.

Immelman se uitgebreide oeuvre bestryk volgens Rousseau (2009:12, 2013:5) meer as 40 romans, 140 kortverhale, 10 vervolgverhale, 300 artikels, 2000 koerantrubrieke asook sketse onder sy eie naam of onder skuilname (soos bv. Rya Avenant).

Van Rooyen (2002) toon aan dat die waarskynlikste lesers van Immelman se fiksie wit Afrikaanse tienerseuns tussen die ouderdomme van 13-18 jaar is, maar dat dit ook sal spreek tot volwassenes wat verhale in die tradisie van die Amerikaanse 'western' verkies. Hy vergelyk die avontuur- en jagverhale van Immelman met die 'frontier fiction' van Amerika en munt die term 'oor-grens'-fiksie met verwysing na Immelman se tekste: juis omdat die karakters dikwels 'n reis na onbekende terrein onderneem, maar terselfdertyd ook 'n simboliese reis na 'die ongekarteerde ruimtes van die gedagtewêreld' (Van Rooyen 2002).

Die groot maroelas speel af op die beesplaas Omugongo naby Tsumeb in die ou Suidwes. Die plaas word bewoon deur die Wagner-gesin (bestaande uit Hans, Bettie en hulle tienerkinders, Petrus en Heidi) asook hulle Ovambo-arbeiders. Op die buurplaas, Toekoms, woon die wewenaar Gert Cloete en sy dogter, Martie. Cloete het voorheen in Angola geboer en wanneer Petrus neerhalend na die gesin as 'die Angolas' (2011:24) verwys, word hy deur sy pa tereggewys. Bettie Wagner ontferm haar oor die buurdogter en nooi die Cloetes soms oor vir ete. Petrus raak in die proses, voorspelbaar genoeg, verlief op Martie Cloete. Ten spye van die tydelike bedreiging van die Engelse miljoenêrsdogter, June Foulkes, eindig die teks met Petrus en Martie wat hulle liefde aan mekaar verklaar.

Die verhaalgebeure in Diegroot maroelas sentreer rondom die stryd tussen Petrus Wagner en diejong leeumannetjie wat (in die openingstoneel van die teks) sy pa se been so beseer dat laasgenoemde daarna toenemend sukkel om sy boerderyverpligtinge na te kom. Die leeumannetjie word tydens dié skermutseling met Hans Wagner gekwes en word daarna uitgeken aan sy af oor. In verskeie insidente van beesvangery asook die aanval op Gert Cloete word die afoorleeu weer geïmpliseer.

Die veertienjarige Petrus is ' $n$ kranige jagter en met sy splinternuwe Mauser skiet hy koedoes by die mielielande (en eenmaal verkeerdelik ook sonder permit ' $n$ eland). Dié jagsessies word deurentyd geregverdig deur klem te lê op verantwoordelike jagpraktyke en die vleis word agterna altyd tussen die jagter en sy handlangers verdeel. Wanneer die aanstellerige Richard Foulkes vir Petrus uitdaag om sy jagvernuf ten toon te stel deur ' $n$ horingbekvoël te skiet, wys 
Petrus hom op die sinneloosheid van die daad en bied aan om eerder die tak onder die voël uit te skiet: 'Toe die skoot dreun, ruk die tak van die boom en die horingbekvoël vlieg skreeuend weg' Die jong afoorleeu bly egter vir Petrus oor 'n periode van drie na vier jaar ontwyk en by meer as een geleentheid word hy deur die leeumannetjie uitoorlê.

Hennie Aucamp (1999:381) verklaar in Wys my waar is Timboektoe: ' $n$ Persoonlike reis deur Afrika met verwysing na een van Henk Rall (1991) se ikoniese jagverhale ('Omba muungu') dat talle jagverhale op twee vlakke afspeel; enersyds feitelik (soos by P.J. Schoeman en Sangiro), maar andersyds ook metafisies, aangesien die eintlike jag in die gemoed van die jagter afspeel. Op een vlak is daar dus die tweestryd met die jong leeu, maar op 'n ander vlak sinjaleer die skiet van die leeu ' $n$ deurgangsrite: 'n volwassewording van seun na man. Visagie (2000) wys immers op die moontlikheid dat geweld (oorlog en jag) as een van die wesenlike grondstene beskou kan word waarop manlike subjektiwiteit gekonstrueer word.

In sy voorwoord tot Henk Rall (1991) se Jagtye: 'n Keur van jagervarings uit Suider-Afrika voer Henk van Dyk, 'n voormalige president van die Suid-Afrikaanse Jagters- en Wildbewaringsvereniging, aan dat daardie tekste waarin daar 'respek' vir die dier getoon word, juis om daardie rede besondere gevoelswaarde het. Wanneer Petrus uiteindelik die leeu in die slottoneel skiet, blyk dit dat die dier se gekweste oor al weggevreet is deur die maaiers en dat hy in ondraaglike pyn moes verkeer:

En meteens is Petrus bly. Bly dat hy hierdie arme dier uit sy pyn en lyding en ellende verlos het. Sal hy die vel wil afslag? Nee, hierdie vel wil hy nie hê nie. Hy wil nie onthou hoe hierdie dier gely het nie. (bl. 259)

Petrus se respek vir die leeumannetjie word weer bevestig wanneer hy op Martie se opmerking dat dit 'wonderlik' is dat hy die leeu geskiet het, somber antwoord: 'Dit was nie wonderlik nie'.

Soos met die meeste herdrukke van ouer tekste, blyk die gedateerde verwysingsraamwerk van die teks onder meer uit die konserwatiewe gewoontes van die karakters asook die talle paternaliserende verwysings na die plaasarbeiders. Protea Boekhuis het reeds talle van Immelman se bekendste titels (soos Kurt Mauser, Die bul van Kashimbo en Die wit hings van die Namib) herdruk en noop lesers in die proses om dié tekste te herwaardeer as argiewe waarin verlore wêrelde vasgelê word. By hierdie storieverteller se afsterwe in Maart 2013 bring die uitgewer, Nicol Stassen (2013:143), soos volg hulde aan die legendariese Doc Immelman: 'Die woorde "wanneer 'n ou man in Afrika sterf, gaan 'n hele biblioteek verlore", geld beslis vir Doc'.

Ten slotte: dié heruitgawe sal waarskynlik die meeste byval vind by geharde Immelman-lesers. Die gedateerde verwysingsraamwerk waarna hierbo verwys is, mag ongelukkig dalk in die pad staan van potensiële nuwe volgelinge.

\section{Literatuurverwysings}

Aucamp, H., 1999, Wys my waar is Timboektoe: 'n Persoonlike reis deur Afrika, Tafelberg, Kaapstad.

La Vita, M., 1994, 'Hemingway van Namibië', Keur, 19 Augustus, bl. 18.

Rall, H., 1991, Jagtye: 'n Keur uit jagervarings uit Suider-Afrika, Human \& Rousseau, Kaapstad.

Rousseau, L., 2009, 'Lewende legende', Die Burger, 8 Augustus, bl. 12.

Rousseau, L., 2013, 'Nóóit weer iemand soos Doc', By, 16 Maart, bl. 5.

Smith, C., 2002, 'Taaie Doc nog vol stories', Die Burger, 09 Desember, bl. 6.

Stassen, N., 2013, “n Hele biblioteek verlore', Weg, Junie 2013, bl. 143.

Van Rooyen, P., 2002, 'Doc Immelman in Namibies-Afrikaanse letterkunde: 'n Analise van rasse- en genderstereotipering in sy werk', MA-verhandeling, Universiteit van Namibië, Windhoek.

Visagie, A., 2000, 'Manlikheid en magsverlies in die Afrikaanse jagliteratuur sedert 1994: Die olifantjagters van Piet van Rooyen en Groot vyf van Johann Botha', Stilet 12 , Junie, $27-42$ 